\title{
LXXII. On the composition of the fire-damp of the newcastle coal mines
}

\section{Thomas Graham Esq. F.R.S.}

To cite this article: Thomas Graham Esq. F.R.S. (1846) LXXII. On the composition of the firedamp of the newcastle coal mines, Philosophical Magazine Series 3, 28:189, 437-440, DOI: $10.1080 / 14786444608645455$

To link to this article: http://dx.doi.org/10.1080/14786444608645455

$$
\text { 曲 Published online: } 30 \text { Apr } 2009 .
$$

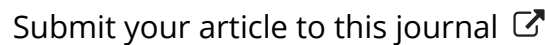

Џ Article views: 2 
Prof. Graham on the Composition of Fire-Damp. 437

agent is produced that forms on mixing hyponitric acid with water; and it appears also that tin engenders with dilute nitric acid a deoxidizing matter, i.e. a nitrate of protoxide of tin.

LXXII. On the Composition of the Fire-Damp of the Nerocastle Coal Mines. By Thomas Graham, Esq., F.R.S.*

GOME years ago I examined the gas of these mines, with $D$ the same result as Dr. Henry, Davy and Dr. Turner had previously obtained, namely, that it contains no other combustible ingredient than light carburetted hydrogen. But the analysis of the gas of the coal mines in Germany, subsèquently published, showing the presence of other gases, particularly of olefiant gas, has rendered a new examination of the gas of the English mines desirable. The gases were,-1, from a seam named the Five-Quarter seam, in the Gateshead colliery, where the gas is collected as it issues, and used for lighting the mine; 2 , the gas of Hebburn colliery, which issues from a bore let down into the Bensham seam-a seam of coal which is highly charged with gas, and has been the cause of many accidents; and 3, gas from Killingworth colliery, in the neighbourhood of Jarrow, where the last great explosion occurred. This last gas issues from a fissure in a stratum of sandstone, and has been kept uninterruptedly burning, as the means of lighting the horse-road in the mine, for upwards of ten years, without any sensible diminution in its quantity. The gases were collected personally by my friend $\mathrm{Mr}$. J. Hutchinson, with every requisite precaution to ensure their purity, and prevent admixture of atmospheric air.

The usual eudiometrical process of firing the gases with oxygen was sufficient to prove that they all consisted of light carburetted hydrogen, with the exception of a few per cent. The results were as follows:-

Gateshead Gas.-Specific gravity 0.5802.

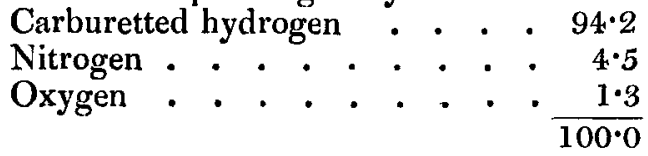

The density of such a mixture is, by calculation, 0.5813 .

Killingworth Gas. - Specific gravity 0`6306.

$$
\begin{aligned}
& \text { Carburetted hydrogen . . . . } 82.5 \\
& \text { Nitrogen . . . . . . . . . 16.5 } \\
& \text { Oxygen . . . . . . . } \frac{1 \cdot 0}{100 \cdot 0}
\end{aligned}
$$

* Communicated by the Chemical Society; having been read November $3,1845$. 
The theoretical density of this gas, deduced from its composition, is 0.6908 .

The Hebburn gas was of specific gravity 0'6327.

Seventy-nine measures of the Killingworth gas, mixed with an equal volume of chlorine, left in the dark for eighteen hours, and afterwards washed with alkali, were reduced to 75 measures ; from which the presence of 4 measures of olefiant gas might be inferred. But in a comparative experiment made at the same time on 25.3 measures of pure gas of the acetates, mixed with an equal volume of chlorine, a contraction occurred of 1.3 measure; that is, in exactly the same proportion as with the fire-damp.

It was observed that phosphorus remains strongly luminous in these gases, mixed with a little air, while the addition to them of one-four-hundredth part of olefiant gas, or even a smaller proportion of the volatile hydrocarbon vapours, destroyed this property. Olefiant gas itself, and all the allied hydrocarbons, were thus excluded.

Another property of pure light carburetted hydrogen, observed by myself, enabled me to exclude other combustible gases, namely, that the former gas is capable of entirely resisting the oxidating action of platinum black, and yet permits other gases to be oxidated which are mixed with it even in the smallest proportion, such as carbonic oxide and hydrogen, the first slowly and the last very rapidly; air or oxygen gas being, of course, also present in the mixture. Now platinum black had not the smallest action on a mixture of the gas from the mines with air. No moisture appeared or sensible contraction, and no trace of carbonic acid could be discovered after a protracted contact of twenty-four hours; while, with the addition of one per cent. of hydrogen, the first effects were conspicuously evident in three mimutes, and with the same proportion of carbonic oxide, the gas became capable of affecting lime-water in half an hour. These experiments were repeated upon each of the three specimens of fire-damp.

Potassium fused in the fire-damp did not become covered with the green fusible compound of carbonic oxide, nor occasion any contraction. Indeed, however carefully the heat was applied to the potassium by menns of an oil-bath, a slight permanent expansion always ensued. The same thing occurred in pure gas of the acetates. It appeared that potassium could not be heated above $300^{\circ} \mathrm{Fahr}$. in pure carburetted hydrogen, without causing a decomposition and the evolution of free hydrogen gas.

The gas was also inodorous, and clearly contained no appreciable quantity of any other combustible gas than fight 
carburetted hydrogen. The only additional matters present were nitrogen and oxygen; the specimen collected in the most favourable circumstances for the exclusion of atmospheric air, namely, that from the Bensham seam, still containing 0.6 per cent. of oxygen. The gases also contained no carbonic acid.

It is worthy of observation, that nothing oxidable at the temperature of the air is found in a volatile state associated with the perfect coal of the Newcastle beds. The remarkable absence of oxidability in light carburetted hydrogen appears to have preserved that alone of all the combustible gases originally evolved in the formation of coal, and which are still found accompanying the imperfect lignite coal of Germany, of which the gas has been examined. This fact is of geological interest, as it proves that an almost indefinitely protracted oxidating action of the air must be taken into account in the formation of coal; air finding a gradual access through the thickest beds of superimposed strata, whether these strata be in a dry state or humid.

In regard to measures for preventing the explosion of the gas in coal mines, and of mitigating the effects of such accidents, I confine myself to two suggestions. The first has reference to the length of time which the fire-damp, from its lightness, continues near the roof, without mixing uniformly with the air circulating through the workings. It was found that a glass jar, of six inches in length and one inch in diameter, filled with fire-damp, and left open with its mouth downwards, continued to retain an explosive mixture for twenty minutes. Now it is very desirable that the fire-damp should be mingled as soon as possible with the whole circulating stream of air, as beyond a certain degree of dilution it ceases to be explosive. Mr. Buddle has stated, "that immediately to the leeward of a blower, though for a considerable way the current may be highly explosive, it often happens that after it has travelled a greater distance in the air-course, it becomes perfectly blended and mixed with the air, so that we can go into it with candles; hence, before we had the use of the Davy lamp, we intentionally made 'long runs,' for the purpose of mixing the air." It is recommended that means be taken to promote an early intermixture of the fire-damp and air; the smallest force is sufficient for this purpose; as a downward velocity of a few inches in the second will bring the light gas from the roof to the foor. 'The circulating stream might be agitnted most easily by a light portable wheel, with vanes, turned by a boy, and so placed as to impel the air in the direction of the ventilation, and not to impede the draft. The gas at the roof undoubtedly often acts as an explosive train, 
conveying the combustion to a great distance through the mine, while its continuity would be broken by such mixing, and an explosion, when it occurred, be confined within narrower limits.

Secondly, no effective means exist for succouring the miners after the occurrence of an explosion, although a large proportion of the deaths is not occasioned by fire, or injuries from the force of the explosion, but from suffocation by the after-damp, or carbonic acid gas, which diffuses itself afterwards through all parts of the mine. It is suggested that a cast-iron pipe, from eight to twelve inches in diameter, be permanently fixed in every shaft, with blowing apparatus, above, by which air could be thrown down, and the shaft itself immediately ventilated after the occurrence of an explosion. It is also desirable that, by means of fixed or flexible tubes, this auxiliary circulation should be further extended, and carried as far as practicable into the workings.

LXXIII. Observations on the Resin of the Xanthorœa hastilis, or Yellow Gum-resin of Nerw Holland. By JoHN Stenhouse, Esq., Ph.D.*

THIS remarkable resin, which is known in commerce as the yellow gum or acaroid resin of Botany Bay, exudes from the Xanthorcea hastilis, a tree which grows abundantly in New Holland, especially in the neighbourhood of Sidney. This resin was first described in Governor Phillips's Voyage to New South Wales in 1788 . Mr. Phillips states that it was employed by the natives and first settler's as a medicine in cases of diarrhœa. The resin as it occurs in commerce sometimes forms masses of considerable size, but as it is very brittle, although tolerably hard, it usually arrives in the state of a coarse powder. Its colour is a deep yellow, with a slightly reddish shade, considerably resembling gamboge, but darker and less pleasing. The colour of its powder is greenish yellow. When chewed it does not dissolve or stick to the teeth, but tastes slightly astringent and aromatic like storax or benzoin. Its smell is very agreeable and balsamic. When gently heated it melts, and when strongly heated it burns with a strong smoky flame, and emits a fragrant odour resembling balsam of Tolu. The resin contains a trace of an essential oil, to which much of its agreeable smell is probably owing. This oil passes into the receiver when the resin is

* Communicated by the Chemical Society; having been read November 17,1845 . 